\title{
Oridonin increases anticancer effects of lentinan in HepG2 human hepatoblastoma cells
}

\author{
ZHIQIANG SUN ${ }^{1}$, QINGHE HAN ${ }^{2}$, LIWEI DUAN ${ }^{2}$, QINGHAI YUAN ${ }^{2}$ and HUI WANG ${ }^{1}$ \\ ${ }^{1}$ Department of Interventional Center, Jilin Provincial Cancer Hospital, Changchun, Jilin 130012; \\ ${ }^{2}$ Department of Radiology, The Second Hospital of Jilin University, Changchun, Jilin 130022, P.R. China
}

Received March 6, 2016; Accepted July 27, 2017

DOI: $10.3892 / \mathrm{ol} .2017 .7485$

\begin{abstract}
The aim of the present study was to investigate whether oridonin is able to increase the effects of lentinan (LNT) in HepG2 human hepatoblastoma cells by MTT, flow cytometry, reverse transcription-quantitative polymerase chain reaction and western blot analysis. The in vitro results demonstrated that $20 \mu \mathrm{g} / \mathrm{ml}$ of oridonin was a nontoxic concentration for L02 normal liver cells and HepG2 liver cancer cells. Furthermore, treatment with $0-200 \mu \mathrm{g} / \mathrm{ml}$ LNT was only able to decrease the viability of HepG2 liver cancer cells. The growth inhibitory rate of the LNT-L $(100 \mu \mathrm{g} / \mathrm{ml})$ treatment group was $20.7 \%$ and the rate of the LNT-H $(200 \mu \mathrm{g} / \mathrm{ml})$ treatment group was $54.8 \%$. Notably, the growth inhibitory rate of the oridonin + LNT-H group was $84.3 \%$. The highest percentage of apoptotic cells was observed in the oridonin + LNT-H group (20 $\mu \mathrm{g} / \mathrm{ml}$ oridonin and $200 \mu \mathrm{g} / \mathrm{ml} \mathrm{LNT}$ ). The percentage of apoptotic cells in the oridonin + LNT-H group was significantly different from the percentage of apoptotic cells in the LNT-H (26.1\%) and the LNT-L (16.8\%) groups. Treatment with LNT produced an increase in caspase-3, caspase-9, Bcl-2-like protein $4, \mathrm{p} 53$, p21, nuclear factor $\kappa \mathrm{B}$ inhibitor- $\alpha$ mRNA and protein expression and a decrease in B-cell lymphoma 2 and nuclear factor- $\kappa \mathrm{B}$ expression in HepG2 cells compared with untreated control cells. Treatment with a combination of oridonin and LNT-H induced a further increase in expression with the biggest differences in expression observed between the oridonin + LNT-H group and control. It was observed that treatment with oridonin was able to increase the anticancer effects of LNT in HepG2 cells. Therefore, oridonin may be used to sensitize cells to LNT.
\end{abstract}

Correspondence to: Professor Hui Wang, Department of Interventional Center, Jilin Provincial Cancer Hospital, 1018 Huguang Road, Changchun, Jilin 130012, P.R. China

E-mail: ccsunzhiqiang@foxmail.com

Dr Qinghai Yuan, Department of Radiology, The Second Hospital of Jilin University, 218 Ziqiang Street, Changchun, Jilin 130022, P.R. China

E-mail: qinghaiyuan@foxmail.com

Key words: oridonin, lentinan, HepG2 human hepatoblastoma cells, growth inhibition, expression

\section{Introduction}

Lentinan (LNT) is a type of medicinal polysaccharide isolated from shiitake with various activities including, immune regulation, anti-tumor, anti-virus and anti-infection effects. LNT has high efficacy and limited side effects (1). LNT has good curative effects on gastric, colon, breast and lung cancer, which is able to prolong the survival time of patients with tumor (2). LNT is often used as an immune enhancer in clinical application, which can enhance curative effects or reduce side effects in combination with other drugs (2). Murata et al (3) reported that a combination of cisplatin and lentinan significantly increased the anti-cancer activity in the treatment of colon cancer. Drandarska et al (4) demonstrated that treatment with LNT is able to increase the activation of Bacillus Calmette-Guérin (BCG)-induced pulmonary macrophages in guinea pigs and reduce systemic adverse reactions of BCG vaccine.

Oridonin is an ent-kaurene diterpenoid compound mainly isolated from $R$. rubescen (5). Previous studies have reported that oridonin is able to promote tumor cell apoptosis $(3,6)$. Apoptotic rate has been hypothesized to have an effect on the sensitivity of tumors to radiation (7). A previous study also indicated that the sensitization effect of oridonin may enhance the efficacy of radiotherapy in liver cancer cell lines (8).

An ideal cancer therapeutic would be a drug that can induce differentiation and apoptosis of tumor cells. Previous clinical studies have focused on Chinese medicine preparations based on anti-proliferative effects, while in recent years the focus has shifted to the development of preparations which can induce differentiation and apoptosis of cancer cells $(9,10)$. Drugs that induce apoptosis can selectively target cancer cells and therefore normal cells are unaffected by treatment (9).

A number of active chemical substances in natural plants have strong apoptotic-inducing effects on cancer cells (8-10), and studies have demonstrated that lentinan and oridonin are active substances with cancer cell apoptosis-inducing effects $(3,8)$.

Substances that can induce apoptosis in cancer cells, which are extracted from plants have a low level of toxicity and can be safely used. These substances are also able to relieve pain in the process of treatment. However, the efficacy of numerous cancer inhibitor components in plants is much lower compared with synthetic drugs (11). Therefore, a combination of different 
natural substances can increase the inhibitory and therapeutic effects (11).

Finding a reasonable combination is an important aspect of the research in the anti-cancer activities of natural products. By studying how oridonin is able to increase the anticancer effect of lentinan in vitro, the present study aimed to verify the effects of a novel combination of anti-cancer substances. By using MTT assay, flow cytometry, reverse transcription-quantitative polymerase chain reaction (RT-qPCR) and western blotting, the present study investigated the effect of oridonin treatment on growth inhibition hepatoblastoma cells in vitro. The study also investigated the effect of lentinan treatment on the apoptosis of hepatoblastoma cells, in order to accumulate further data that may enable future animal experiments and even clinical application.

\section{Materials and methods}

Cell lines and treatments. Human normal liver L02 cell lines and human hepatoblastoma HepG2 cells were purchased from the Conservation Genetics CAS Kunming Cell Bank (Kunming, China). Oridonin and lentinan were purchased from Shanghai Shamrock Imp and Exp Trading Co., Ltd. (Shanghai, China). Lentinan-Low (LNL-L, $100 \mu \mathrm{g} / \mathrm{ml}$ ) and Lentinan-High (LNL-H, $200 \mu \mathrm{g} / \mathrm{ml}$ ) treatment groups were generated for the two cell lines.

Cell culture. The normal human liver L02 cell lines (control group) and human hepatoblastoma HepG2 cells were cultured in RPMI-1640 medium (Gibco; Thermo Fisher Scientific, Inc., Waltham, MA, USA) supplemented with $10 \%$ fetal bovine serum (Gibco; Thermo Fisher Scientific, Inc.) and cultured in an incubator under humidified atmosphere of $5 \% \mathrm{CO}_{2}$ at $37^{\circ} \mathrm{C}$. The medium was changed 2-3 times a week and sub-cultured for 6-7 days. Subsequently, the cells were seeded in a 96-well culture plate at a density of $1 \times 10^{4} / \mathrm{ml}$ with $180 \mu \mathrm{l}$ per well, and cultured for $24 \mathrm{~h}$ under humidified atmosphere of $5 \% \mathrm{CO}_{2}$ at $37^{\circ} \mathrm{C}$.

MTT assay. The L02 (control group) and HepG2 cells were incubated with Oridonin $(20 \mu \mathrm{g} / \mathrm{ml})$ and Lentinan $(100 \mu \mathrm{g} / \mathrm{ml})$ for $24 \mathrm{~h}$ at room temperature, respectively. After $24 \mathrm{~h}, 20 \mu \mathrm{l}$ MTT solution $(5 \mathrm{mg} / \mathrm{ml}$; Ameresco Inc., Framingham, MA, USA) was added to each well and incubated at $37^{\circ} \mathrm{C}$ for $4 \mathrm{~h}$, following which the culture medium was replaced with $150 \mu \mathrm{l}$ dimethyl sulfoxide (Sigma-Aldrich; Merck KGaA, Darmstadt, Germany). The absorbance was measured at $540 \mathrm{~nm}$ using a microplate spectrophotometer (Bio-Rad Laboratories, Inc., Hercules, CA, USA). The following formula was used to calculate the inhibitory rate: Percentage cell viability $=[$ (Absorbance of untreated cells-absorbance of treated cells)/absorbance of untreated cells] x100 (12).

Flow cytometry analysis of cell cycle distribution and apoptosis. HepG2 cells were seeded at a density of $50 \times 10^{4}$ cells/60-mm dish and incubated overnight at $37^{\circ} \mathrm{C}$. Oridonin was added to a final concentration of $40 \mu \mathrm{M}$ and cells were incubated for $24 \mathrm{~h}$ at $37^{\circ} \mathrm{C}$. The cells were treated as follows: i) $20 \mu \mathrm{g} / \mathrm{ml}$ oridonin + $200 \mu \mathrm{g} / \mathrm{ml}$ lentinan; ii) PBS (negative control); iii) $100 \mu \mathrm{g} / \mathrm{ml}$ lentinan; and iv) $200 \mu \mathrm{g} / \mathrm{ml}$ lentinan. Detached and adherent cells were collected and centrifuged at $1,500 \mathrm{x} \mathrm{g}$ for $5 \mathrm{~min}$ at $4^{\circ} \mathrm{C}$. Pellets were rinsed with ice-cold PBS and fixed with $70 \%$ ethanol at $4^{\circ} \mathrm{C}$ overnight. The density of HepG2 cells was adjusted to $5 \times 10^{5}$ cells $/ \mathrm{ml}$, and the cells were washed with PBS three times. Cells were subsequently stained with staining buffer (PBS containing $20 \mu \mathrm{g} / \mathrm{ml}$ of propidium iodide, $100 \mu \mathrm{g} / \mathrm{ml} \mathrm{RNase}$ A and 0.1\% Triton X-100; BD Biosciences, Franklin Lakes, NJ, USA) for $15 \mathrm{~min}$ at $4^{\circ} \mathrm{C}$ in the dark. The cells were subsequently labeled with Annexin V-fluorescein isothiocyanate (FITC) and propidium iodide (Annexin V-FITC apoptosis detection kit; BD Biosciences; cat. no. 556547). Samples were analyzed using a flow cytometer (BD Biosciences) and Cell Quest acquisition software (version 2.9; BD Biosciences) (13).

Reverse transcription-quantitative polymerase chain reaction $(R T-q P C R)$ assay. Cells from different treatment groups $(20 \mu \mathrm{g} / \mathrm{ml}$ oridonin $+200 \mu \mathrm{g} / \mathrm{ml}$ lentinan; PBS as negative control; $100 \mu \mathrm{g} / \mathrm{ml}$ lentinan; and $200 \mu \mathrm{g} / \mathrm{ml}$ lentinan) were collected, and total RNA was extracted using TRIzol reagent (Invitrogen; Thermo Fisher Scientific, Inc.), according to the manufacturer's protocol. Total RNA was reverse transcribed into cDNA using a cDNA reverse transcription kit (cat. no., 1708840; Bio-Rad Laboratories, Inc.) according to manufacturer's protocol. The resultant DNA $(10 \mu \mathrm{l})$ was subjected to a $25 \mu \mathrm{l}$ PCR conducted in an iCycler thermal cycler (Bio-Rad Laboratories, Inc.) using iQ SYBR Green Supermix (Bio-Rad Laboratories, Inc.). The thermocycling conditions that were used were as follows: Initial denaturation at $95^{\circ} \mathrm{C}$ for $5 \mathrm{~min}$, followed by 35 cycles at $95^{\circ} \mathrm{C}$ for $20 \mathrm{sec}, 58^{\circ} \mathrm{C}$ for $20 \mathrm{sec}$ and $72^{\circ} \mathrm{C}$ for $20 \mathrm{sec}$, with a final extension of $72^{\circ} \mathrm{C}$ for $5 \mathrm{~min}$. $\beta$-actin was used as the internal reference gene. The relative expression levels were calculated using the $2^{-\Delta \Delta \mathrm{Cq}}$ method (14) and gene expression was normalized to $\beta$-actin. The primers used in the present study were as follows: B-cell lymphoma $(\mathrm{Bcl})-2$ forward, 5'-CAAAGGTGGATCAGATTCAAG-3'; Bcl-2 reverse, 5'-GGTGAGCATTATCACCCAGAA-3'; Bcl-2-associated protein X (Bax) forward, 5'-TGGCAGCAGTGACAGCAG CG-3'; Bax reverse, 5'-TACGGAGGTGGAGTGGGTGT-3'; caspase-3 forward, 5'-AAAGTTTTCAATGACCAAGC-3'; caspase-3 reverse, 5'-TCTGACGAATCTCCTCCAC-3'; caspase-9 forward, 5'-AGTCTATTTTATTATGGGCTCG-3'; caspase-9 reverse, 5'-TGGATGTTTATGTCACCTTTTC-3'; p21 forward, 5'-ATGGAGAACACTGAAAACTC-3'; p21 reverse, 5'-TGTGAGCATGGAAACAATAC-3'; p53 forward, 5'-ACТСССАТТСТTCСАCСТTTG-3'; p53 reverse, 5'-CCC TGTTGCTGTAGCCATATT-3'; nuclear factor $\kappa \mathrm{B}(\mathrm{NF}-\kappa \mathrm{B})$ forward, 5'-GCTATTCAGGCTGTGCTGTC-3'; NF-кB reverse, 5'-GGTAGTCGGTGAGATCTCGG-3'; nuclear factor $\kappa \mathrm{B}$ inhibitor $\alpha(\mathrm{I} \kappa \mathrm{B}-\alpha)$ forward, 5'-CCAACTATT GCTTCAGCTCCA-3' IкB- $\alpha$ reverse, 5'-GTGTCCAGGCTC CAAATGT-3'; $\beta$-actin forward, 5'-AGCCTTCTCCATGGT CGTGA-3'; and $\beta$-actin reverse, 5'-CGGAGTCAACGGATT TGGTC-3'. Primers were synthesized by Invitrogen; Thermo Fisher Scientific, Inc.

Western blot analysis. HepG2 cells treated with oridonin and/or lentinan as aforementioned were homogenized and lysed with radioimmunoprecipitation assay lysis buffer (Invitrogen; Thermo Fisher Scientific, Inc.; 100 mM NaCl, 
A

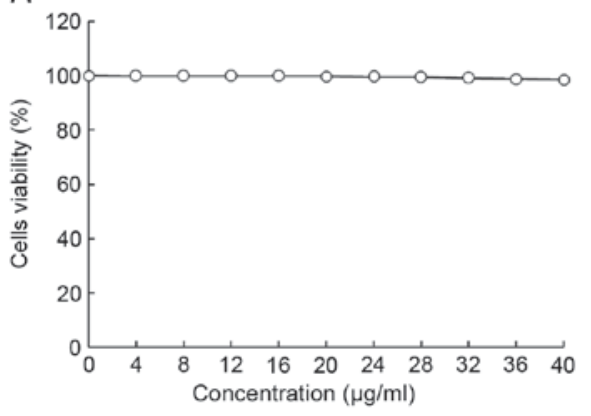

B

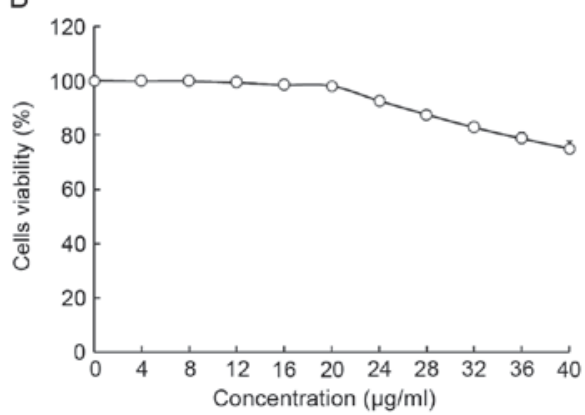

Figure 1. Effect of oridonin treatment on the viability of human normal liver cells (A) L02 and (B) HepG2 human hepatoblastoma cells as determined by MTT assay.
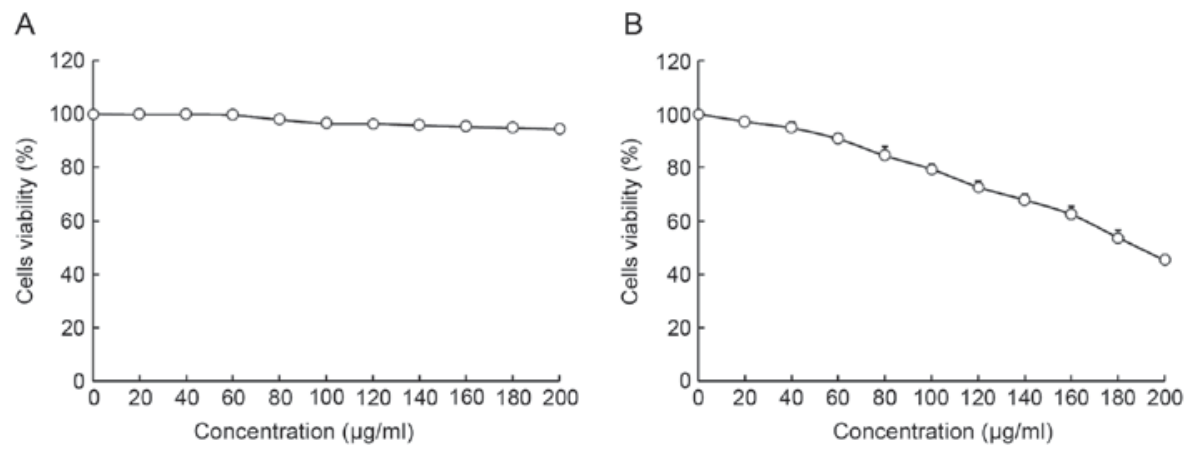

Figure 2. Effect of lentinan treatment on the viability of human normal liver cells (A) L02 and (B) HepG2 human hepatoblastoma cells as determined by MTT assay.

$50 \mathrm{mM}$ Tris-HCl pH 7.5, 1\% Triton X-100, 1 mM EDTA, $10 \mathrm{mM} \beta$-glycerophosphate, $2 \mathrm{mM}$ sodium vanadate and protease inhibitor). Lysates were sonicated for $5 \mathrm{sec}$ on ice and centrifuged at $6,000 \mathrm{x}$ g for $5 \mathrm{~min}$ at $4^{\circ} \mathrm{C}$. Supernatants were collected and the protein concentration was detected using a Bio-Rad protein assay kit (cat. no. 500-0002; Bio-Rad Laboratories, Inc.). A total of $20 \mu \mathrm{g}$ protein/well was loaded to SDS-PAGE (10\% gel; GE Healthcare Life Sciences, Shanghai, China) and transferred onto polyvinylidene difluoride membranes, which were activated by methanol. The membrane was blocked using $10 \%$ skimmed milk at room temperature for $1 \mathrm{~h}$. Subsequently, the membranes were incubated with the primary antibodies against caspase-3 $(1: 1,000$; cat. no. ab13847), caspase-9 (1:1,000; cat. no. ab18571), Bcl-2 (1:1,000; cat. no. ab194583), Bax (1:1,000; cat. no. ab32503), p38 (1:1,000; cat. no. ab31828), p53 (1:1,000; cat. no. ab1431),

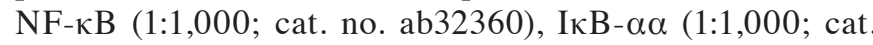
no. ab7217) and $\beta$-actin (1:5,000; cat. no. ab8226), all purchased from Abcam (Cambridge, UK), overnight at $4^{\circ} \mathrm{C}$. The following day, the membranes were washed with TBST for $10 \mathrm{~min}$, prior to incubation with the horseradish peroxidase-conjugated goat anti-mouse IgG secondary antibody (1:1,000; cat. no. ab6728; Abcam) for $1 \mathrm{~h}$ at room temperature and washed three times with TBST (10 min per wash). The membranes were visualized using ECL chemiluminescence agent, and $\beta$-actin was used as a control for normalization. Immunoreactivity was determined using enhanced chemiluminescent reagent (Thermo Fisher Scientific, Inc.) using an ImageQuant Las4000 digital imager (Thermo Fisher Scientific, Inc.).
Statistical analysis. Data are presented as the mean \pm standard deviation. Statistical evaluation was performed using Student's t-test or one-way analysis of variance followed by Student-Newman-Keuls test using SAS (version 9.2; SAS Institute Inc., Cary, NC, USA). $\mathrm{P}<0.05$ was considered to indicate a statistically significant difference.

\section{Results}

Effects of oridonin and lentinan treatment on LO2 and HepG2 cells. The viability of HepG2 and L02 cells following treatment with oridonin or LNT was determined using MTT assay (Figs. 1 and 2). Treatment with $0-20 \mu \mathrm{l} / \mathrm{ml}$ oridonin did not result in a decrease in viability in L02 or HepG2 cells (Fig. 1A and B). It was observed that LNT treatment was able to decrease the viability of HepG2 cells at an increased concentration. Treatment with $0-200 \mu \mathrm{l} / \mathrm{ml}$ LNT was able to decrease the viability of HepG2 cancer cells. However, treatment with the same concentration of LNT did not result in a decrease in viability in L02 cells.

Based on these results, $20 \mu \mathrm{l} / \mathrm{ml}$ oridonin was selected for subsequent experiments to investigate whether oridonin treatment is able to increase the anti-cancer effect of LNT. Concentrations of 100 and $200 \mu \mathrm{l} / \mathrm{ml}$ were selected to verify the anticancer effects of LNT (Fig. 2).

The growth inhibition values of HepG2 human hepatoblastoma cells by oridonin and lentinan are presented in Table I. The highest $\mathrm{OD}_{540}$ value was observed in the HepG2 cancer cells; oridonin + LNT-H $(20 \mu \mathrm{g} / \mathrm{ml}$ oridonin $+200 \mu \mathrm{g} / \mathrm{ml}$ LNT), LNT-H (200 $\mu \mathrm{g} / \mathrm{ml}$ LNT) and LNT-L (100 $\mu \mathrm{g} / \mathrm{ml} \mathrm{LNT})$ treatments were able to decrease the $\mathrm{OD}_{540}$ value compared 
with the cells in the control group. Treatment of HepG2 cells with a combination of $20 \mu \mathrm{g} / \mathrm{ml}$ oridonin and $200 \mu \mathrm{g} / \mathrm{ml} \mathrm{LNT}$ increased the growth inhibitory rate compared with treatment with $200 \mu \mathrm{g} / \mathrm{ml}$ LNT alone (Table I).

DNA content of sub-G1 HepG2 cells. Following treatment of HepG2 cancer cells with LNT, the percentage of apoptotic cells (percentage of sub-G1DNA content) was increased compared with the control cells $(2.3 \pm 0.4 \%$; Fig. 3$)$. The percentage of apoptotic HepG2 cells treated with a high concentration of LNT (LNT-H, $200 \mu \mathrm{g} / \mathrm{ml}$ ) was $28.1 \pm 1.9 \%$, and the percentage of cells treated with a low concentration of LNT (LNT-L, $100 \mu \mathrm{g} / \mathrm{ml}$ ) was $16.8 \pm 1.8 \%$. A nontoxic concentration $(20 \mu \mathrm{g} / \mathrm{ml})$ of oridonin was able to increase the percentage of apoptoticHepG2 cells that were also treated with LNT-H (oridonin + LNT-H vs. LNT-H, $43.7 \pm 2.8$ vs. $28.1 \pm 1.9 \%$; Fig. 3 ).

mRNA and protein expression of caspase-3 and -9 in HepG2 cells. The highest levels of caspase- 3 and -9 mRNA expression were observed in HepG2 cells treated with oridonin and LNT-H, with a 3.10 and 2.51-fold increase compared with the control, respectively (Fig. 4). The oridonin + LNT-H treated HepG2 cells also exhibited higher caspase- 3 and caspase- 9 protein expression compared with the cells in the other groups (control, LNT-L and LNT-H).

Gene and protein expression of Bax and Bcl-2 in HepG2 cells. The levels of Bax mRNA expression in cells treated with oridonin + LNT-H, LNT-H and LNT-L demonstrated a3.71-, 1.70- and 2.42-fold increase compared with the control (Fig. 5). The levels of Bcl-2 mRNA expression in cells treated with oridonin + LNT-H, LNT-H and LNT-L demonstrated a0.21-, 0.48- and 0.76-fold decrease compared with the control. The highest protein expression of Bax was observed in the oridonin + LNT-H treatment group, and the lowest Bcl-2 protein expression was also observed in the oridonin + LNT-H group (Fig. 5).

mRNA and protein expression of p53 and p21 in HepG2 cells. The highest levels of p53 and p21 mRNA and protein expression were observed in the oridonin + LNT-H group. The levels of p53 and p21 were observed to be higher in the oridonin + LNT-H group compared with the LNT-L group (Fig. 6A and B). The levels of p53 and p21 mRNA expression in the oridonin + LNT-H group were 2.37 and 2.25 times higher compared with the control, respectively (Fig. 6A).

$m R N A$ and proteinexpression of $N F-\kappa B$ and I $\kappa B-\alpha$ in Hep 2 cells. Treatment of cells with oridonin and LNT-H was able to reduce $\mathrm{NF}-\kappa \mathrm{B}$ expression and increase $\mathrm{I} \kappa \mathrm{B}-\alpha$ expression compared with the control (Fig. 7). The levels of NF- $\kappa \mathrm{B}$ mRNA was decreased 0.39 -fold and the levels of I $\kappa \mathrm{B}-\alpha$ mRNA were increased 3.72-fold in cells treated with oridonin and LNT-H, compared with control cells (Fig. 7A). There was a similar trend in the expression of $\mathrm{NF}-\kappa \mathrm{B}$ and $\mathrm{I} \kappa \mathrm{B}-\alpha$ proteins as the mRNA expression of these proteins (Fig. 7B).

\section{Discussion}

Liver cancer cell apoptosis has an important role in the development of liver cancer. It is now known that there are a variety
Table I. Growth inhibition of HepG2 human hepatoblastoma cells by oridonin and lentinan as assessed by MTT assay.

\begin{tabular}{lcc}
\hline Treatment & OD $_{540}$ value & Inhibitory rate $(\%)$ \\
\hline Oridonin + LNT-H & $0.076 \pm 0.006^{\mathrm{a}}$ & $84.3 \pm 2.5^{\mathrm{a}}$ \\
Control & $0.484 \pm 0.005^{\mathrm{a}}$ & - \\
LNT-L & $0.384 \pm 0.010^{\mathrm{a}}$ & $20.7 \pm 1.9^{\mathrm{a}}$ \\
LNT-H & $0.219 \pm 0.011^{\mathrm{a}}$ & $54.8 \pm 2.2^{\mathrm{a}}$ \\
\hline
\end{tabular}

${ }^{\text {a }}<0.05$ vs. control, according to Duncan's multiple range test. Oridonin + LNT-H, $20 \mu \mathrm{g} / \mathrm{ml}$ oridonin $+200 \mu \mathrm{g} / \mathrm{ml}$ lentinan; LNT-L, $100 \mu \mathrm{g} / \mathrm{ml}$ lentinan; LNT-H, $200 \mu \mathrm{g} / \mathrm{ml}$ lentinan; OD, optical density.

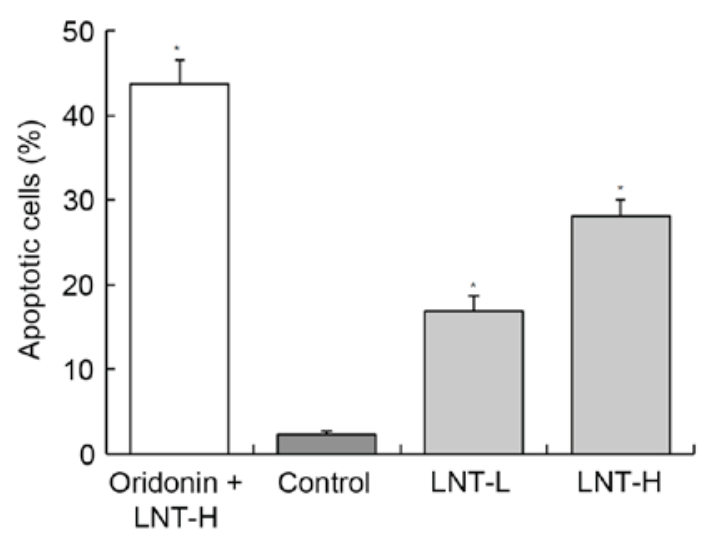

Figure 3. Flow cytometric analysis of the percentage of apoptotic HepG2 human hepatoblastoma cells. The DNA content of the sub-G1 phase was evaluated. ${ }^{a-d *}$ Mean values with different letters over the bars are significantly different $(\mathrm{P}<0.05)$ according to Duncan's multiple range test. Oridonin + LNT-H, $20 \mu \mathrm{g} / \mathrm{ml}$ oridonin $+200 \mu \mathrm{g} / \mathrm{ml}$ lentinan; LNT-L, $100 \mu \mathrm{g} / \mathrm{ml}$ lentinan; LNT-H, $200 \mu \mathrm{g} / \mathrm{ml}$; LNT, lentinan.

of cell signals mediated by receptors involved at the initiation of liver cancer cell apoptosis. There are also a number of proteases involved in apoptosis signal conduction as well as multiple genes involved in the regulation of liver cancer cell apoptosis. In previous years, it has been demonstrated that caspase-3 protease contributes a major function in apoptosis signaling transduction $(15,16)$. The mechanism of caspase- 3 protease activation is highly complex and regulated by various factors, thus there are different activation pathways. The activation of caspase- 3 protease activation is closely associated with liver cancer cell apoptosis. Among the different proteases, caspase-3 has a key role in apoptosis; it is the core protease that causes caspase cascade reactions leading to apoptosis. Caspase- 3 is activated in apoptosis of liver cancer cell and is induced by a variety of factors $(17,18)$. Therefore, by inhibiting the activation and activity of caspase-3, this may inhibit the apoptosis of liver cancer cells (18).

Studies have reported have reported that Bcl-2 family members exert an important regulatory role in the process of caspase-3 activation $(18,19)$. Anti-apoptotic member of Bcl-2 family, Bcl-xL inhibits oligomers of apoptotic protease-activating factor 1 (Apaf-1), which results in the loss-of-function of Apaf-1 molecules and inhibits Apaf-1-dependent activation of caspase-9 (20). Anti-apoptotic 
A
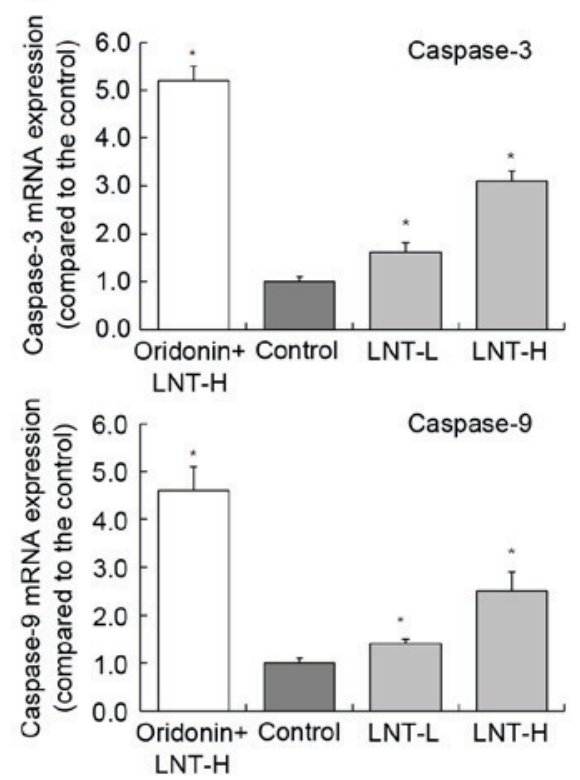

B
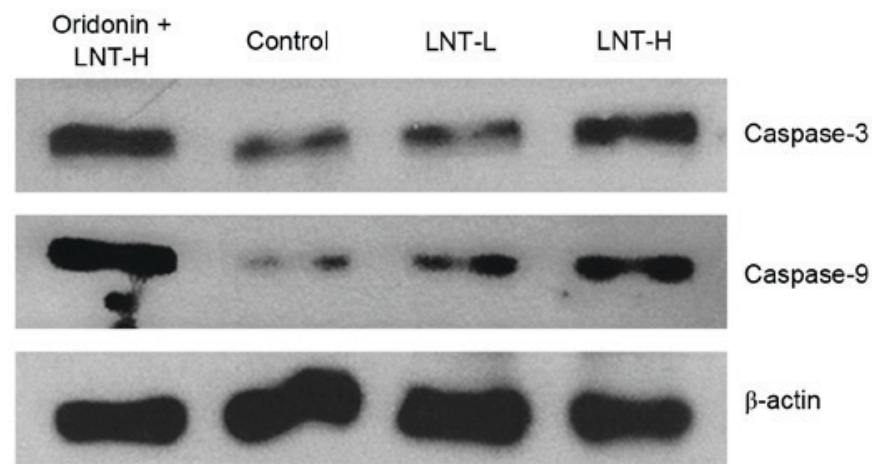

Figure 4. Expression of caspase-3 and caspase-9 in HepG2 human hepatoblastoma cells by reverse transcription-quantitative polymerase chain reaction and western blot analysis. (A) mRNA and (B) protein expression. ${ }^{*} \mathrm{P}<0.05$ vs. control. Oridonin $+\mathrm{LNT}-\mathrm{H}, 20 \mu \mathrm{g} / \mathrm{ml}$ oridonin $+200 \mu \mathrm{g} / \mathrm{ml}$ lentinan; LNT-L, $100 \mu \mathrm{g} / \mathrm{ml}$ lentinan; LNT-H, $200 \mu \mathrm{g} / \mathrm{ml}$ lentinan; LNT, lentinan.
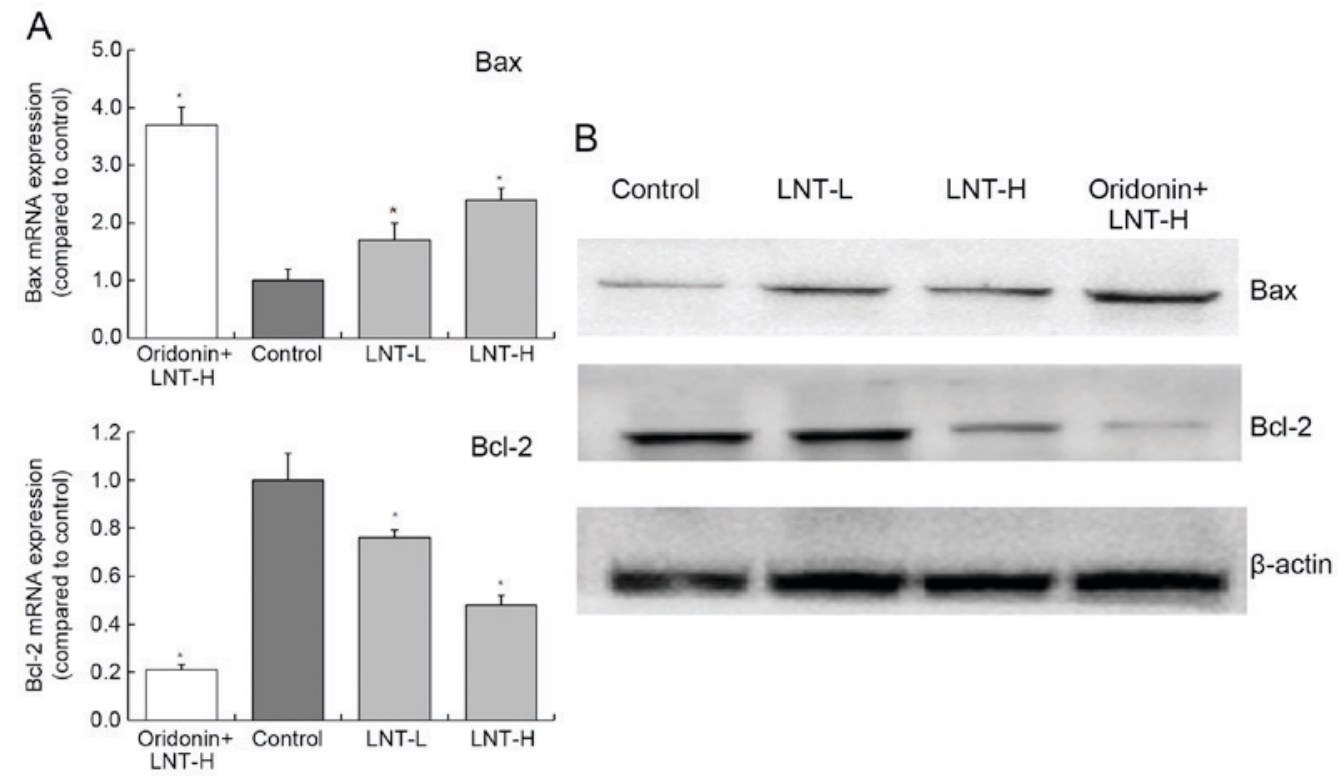

Figure 5. Expression of Bax and Bcl-2 in HepG2 human hepatoblastoma cells by (A) reverse transcription-quantitative polymerase chain reaction and (B) western blot analysis. "P<0.05 vs. control. Oridonin + LNT-H, $20 \mu \mathrm{g} / \mathrm{ml}$ oridonin $+200 \mu \mathrm{g} / \mathrm{ml}$ lentinan; LNT-L, $100 \mu \mathrm{g} / \mathrm{ml}$ lentinan; LNT-H, $200 \mu \mathrm{g} / \mathrm{ml}$ lentinan; Bcl-2, B-cell lymphoma 2; Bax, Bcl-2-like protein 4; LNT, lentinan.

members of the Bcl-2 family, which is primarily present in the outer membrane of the mitochondria, are able to prevent the release of cytochrome $\mathrm{c}$ from the mitochondria, which therefore inhibits the activation of pro-caspase-9 (21).

All pro-apoptosis Bcl-2 family members can form miscellaneous dimers with Bcl-2, Bcl-xL, A1 and Mcl-1 in the $\mathrm{BH} 3$ domain, which demonstrates that pro-apoptosis $\mathrm{Bcl}-2$ family members, at least in part, function by interacting with anti-apoptosis Bcl-2 family members. Pro-apoptosis Bcl-2 family members are also able to induce the activation of caspases (22). Studies have also demonstrated that p53 is able to cause apoptosis through the activation of caspases $(23,24)$. Fuchs et al (25) reported that fas-deficient cells, which induced the expression of wild type p53, are able to activatecaspase-3 expression and characteristic changes in apoptosis, indicating that p53-dependent apoptosis can directly activate caspases, dependent on the involvement of Fas (25). Apoptosis inhibitory factor, $\mathrm{Bcl}-2$, regulates apoptosis by forming dimer by itself or different dimers with Bax protein. An increase in theBcl-2/Bax ratio results in inhibition of apoptosis, yet if the ratio decreases apoptosis is promoted. The mechanism of action of Bcl-xL is similar to that of Bcl-2 (26). Silencing Bcl-2 


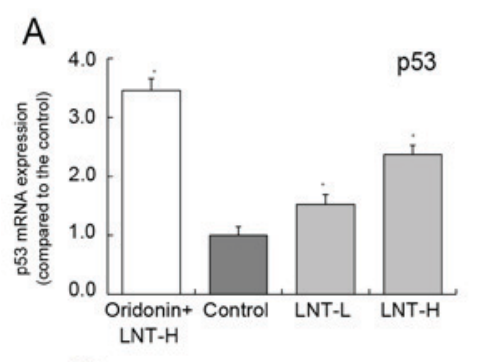

B
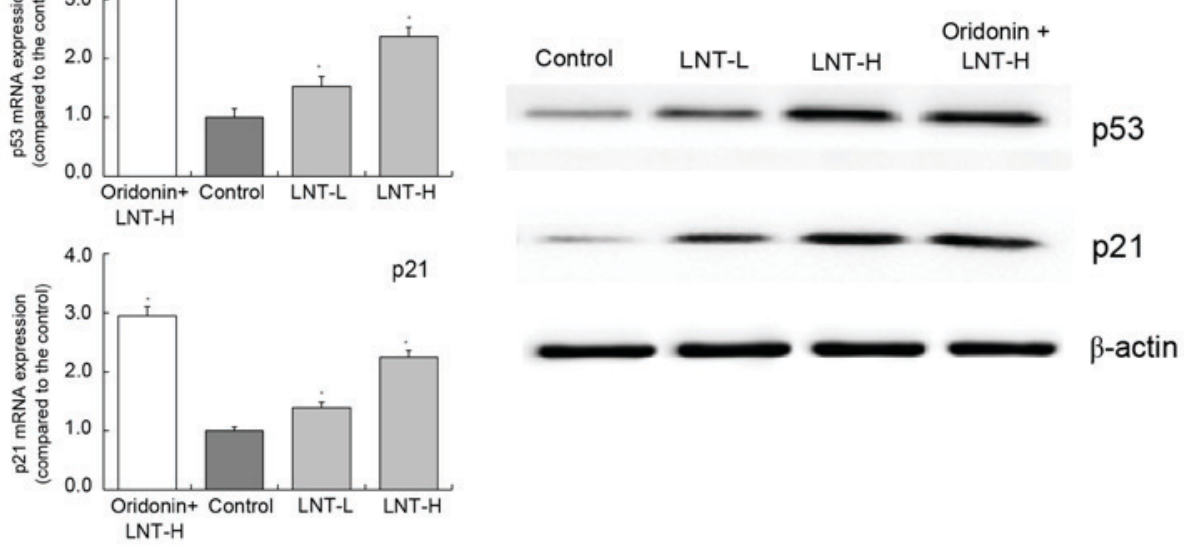

Figure 6. Expression of p53 and p21 in HepG2 human hepatoblastoma cells by (A) reverse transcription-quantitative polymerase chain reaction and (B) western blot analysis. "P<0.05 vs. control. Oridonin + LNT-H, $20 \mu \mathrm{g} / \mathrm{ml}$ oridonin + $200 \mu \mathrm{g} / \mathrm{ml}$ lentinan; LNT-L, $100 \mu \mathrm{g} / \mathrm{ml}$ lentinan; LNT-H, $200 \mu \mathrm{g} / \mathrm{ml}$ lentinan; LNT, lentinan.
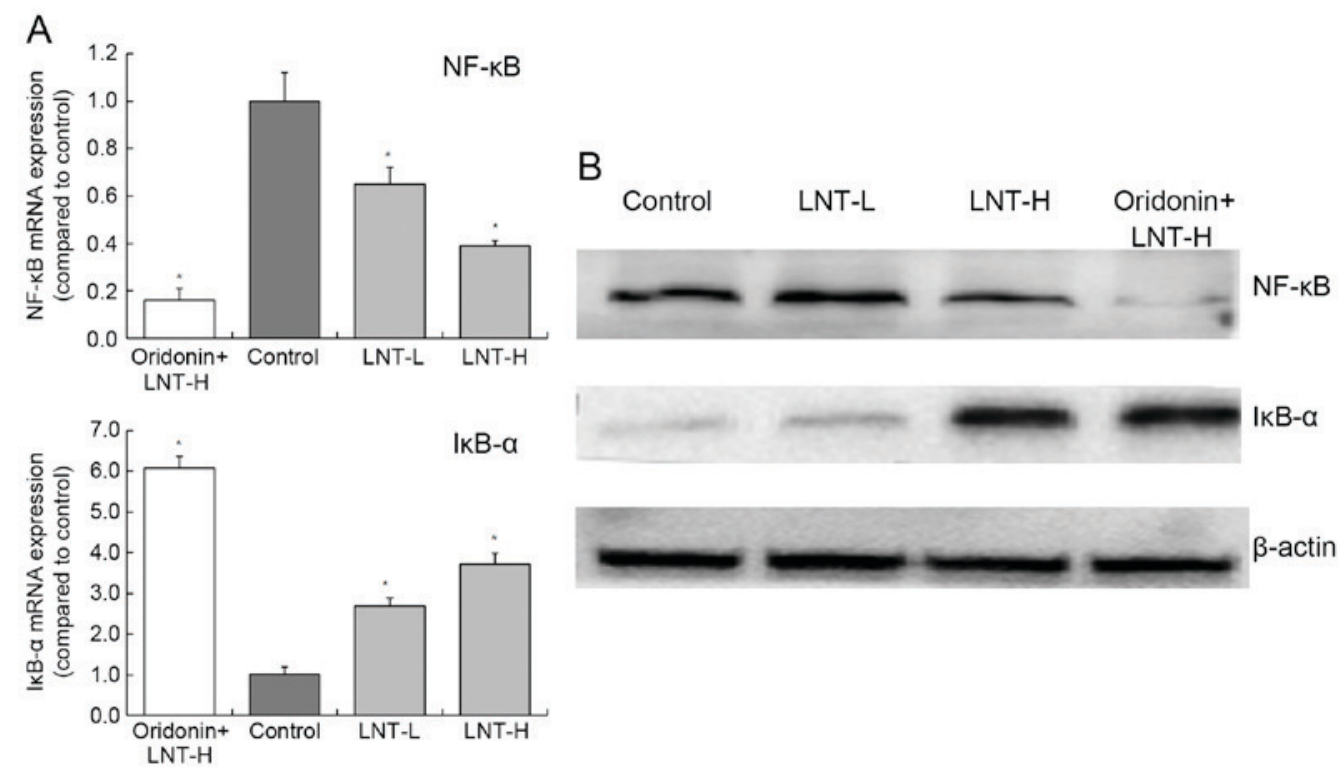

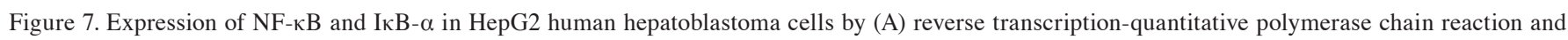
(B) western blot analysis. "P $<0.05$ vs. control. Oridonin $+\mathrm{LNT}-\mathrm{H}, 20 \mu \mathrm{g} / \mathrm{ml}$ oridonin $+200 \mu \mathrm{g} / \mathrm{ml}$ lentinan; LNT-L, $100 \mu \mathrm{g} / \mathrm{ml}$ lentinan; LNT-H, $200 \mu \mathrm{g} / \mathrm{ml}$ lentinan; LNT, lentinan; NF- $\kappa B$, nuclear factor $\kappa \mathrm{B} ; \mathrm{I} \kappa \mathrm{B}-\alpha$, nuclear factor $\kappa \mathrm{B}$ inhibitor $\alpha$.

gene is also able to induce the activation of p53-dependent apoptotic signaling pathway. In p53 wild-type cancer cells, following the activation of $\mathrm{p} 53$, Bax expression increases if the concentration of ultraviolet radiation treatment increases. However, the expression of $\mathrm{Bcl}-2$ and $\mathrm{Bcl}-\mathrm{xL}$ decreases with the increase of inhibitor concentration. These findings indicated that in the process of killing cancer cells by inhibitors, p53 induces apoptosis primarily through the Bax/Bcl-2 and Bax/Bcl-xL signaling pathways (27). Another study has indicated that in cancer cells, ultraviolet radiation may change the expression of p21 through p53, therefore inducing cell cycle arrest. The increase in the expression of p21 and p53 is one of the markers that indicate that ultraviolet radiation is able to induce cancer cell apoptosis (28).
$\mathrm{NF}-\mathrm{KB}$ is a type of nuclear transcription regulatory factor, which is present in the majority of cells. When the cell is not stimulated, NF- $\kappa \mathrm{B}$ and its inhibitor ІкB exist in cytoplasm in an activated form (29). However, when cells are stimulated by cellular damage or viruses, IкB is phosphorylated and degraded. This results in the translocation of $\mathrm{NF}-\mathrm{\kappa B}$ to the nucleus and consequently activation of NF- $\mathrm{KB}$. Following activation, NF- $\kappa \mathrm{B}$ can promote transcription of cytokines, chemokines and adhesion factors (30). In previous years, numerous studies have revealed that NF- $\kappa B$ can control proliferation, regulate cell cycle and apoptosis, affect differentiation, promote tumor metastasis and have a close association with the occurrence and development of tumors $(30,31)$. 
In the present study, MTT, flow cytometry, RT-qPCR and western blot analysis were performed. Treatment with LNT induced a decrease in cell viability in HepG2 cancer cells in a dose-dependent manner, and oridonin treatment promoted the anticancer effects of LNT in vitro. The results from the present study provide evidence that oridonin may be used to sensitize cells to LNT in vitro.

\section{References}

1. Kupfahl C, Geginat G and Hof H: Lentinan has a stimulatory effect on innate and adaptive immunity against murine Listeria monocytogenes infection. Int Immunopharmacol 6: 686-696, 2006.

2. Hou XJ and Chen W: Optimization of extraction process of crude polysaccharides from wild edible $\mathrm{BaChu}$ mushroom by response surface methodology. Carbohyd Polym 72: 67-74, 2008.

3. Murata T, Hatayama I, Kakizaki I, Satoh K, Sato K and Tsuchida S: Lentinan enhances sensitivity of mouse colon 26 tumor to cis-diamminedichloroplatinum (II) and decreases glutathione transferase expression. Jpn J Cancer Res 87: 1171-1178, 1996.

4. Drandarska I, Kussovski V, Nikolaeva S and Markova N: Combined immunomodulating effects of BCG and Lentinan after intranasal application in guinea pigs. Int Immunopharmacol 5: 795-803, 2005

5. Wang RL: Dong ling caozhiliaoyuanfaxingganai 31 li linchuang guan cha. Ai Zheng 3: 50, 1984 (In Chinese).

6. Zhang JF, Chen GH, Lu MQ and Liu JJ: Anti proliferation effects of oridonin on hepatocellular carcinoma BEL-7402 cells and its mechanism. Chinese Traditional Patent Med 28: 1325-1329, 2006.

7. Huang HL, Weng HY, Wang LQ, Yu CH, Huang QJ, Zhao PP, Wen JZ, Zhou H and Qu LH: Triggering Fbw7-mediated proteasomal degradation of c-Myc by oridonin induces cell growth inhibition and apoptosis. Mol Cancer Ther 11: 1155-1165, 2012.

8. Wang $\mathrm{H}$, Yu HS and Xue HW: Radio sensitization effect of oridonin on HepG2 in vitro. Med J Qi lu 22: 339-342, 2007 (In Chinese).

9. Mullard A: Pioneering apoptosis-targeted cancer drug poised for FDA approval. Nat Rev Drug Discov 15: 147-149, 2016.

10. Denisenko TV, Sorokina IV, Gogvadze V and Zhivotovsky B: Mitotic catastrophe and cancer drug resistance: A link that must to be broken. Drug Resist Updat 24: 1-12, 2016.

11. O'Connor SE: Plant biochemistry. Fighting cancer while saving the mayapple. Science 349: 1167-1168, 2015.

12. Zhao X, Wang Q, Li GJ, Chen F, Qian Y and Wang R: In vitro antioxidant, anti-mutagenic, anti-cancer and anti-angiogenic effects of Chinese Bowl tea. J Funct Food 7: 590-598, 2014

13. Zhao X, Qian Y, Zhou YL, Wang R, Wang Q and Li GJ: Pu-erh tea has in vitro anticancer activity in TCA8113 cells and preventive effects on buccal mucosa cancer in U14 cells injected mice in vivo. Nutr Cancer 66: 1059-1069, 2014.

14. Livak KJ and Schmittgen TD: Analysis of relative gene expression data using real-time quantitative PCR and the 2(-Delta Delta C(T)) method. Methods 25: 402-408, 2001
15. Zhao X, Kim SY and Park KY: Bamboo salt has in vitro anticancer activity in HCT-116 cells and exerts anti-metastatic effects in vivo. J Med Food 16: 9-19, 2013.

16. Wong RS: Apoptosis in cancer: From pathogenesis to treatment. J Exp Clin Cancer Res 30: 87, 2011.

17. O'Donovan N, Crown J, Stunell H, Hill AD, McDermott E, O'Higgins $N$ and Duffy MJ: Caspase 3 in breast cancer. Clin Cancer Res 9: 738-742, 2003.

18. Rodríguez-Berriguete G, Galvis L, Fraile B, de Bethencourt FR, Martínez-Onsurbe P, Olmedilla G, Paniagua R and Royuela M: Immunoreactivity to caspase-3, caspase-7, caspase-8, and caspase-9 forms is frequently lost in human prostate tumors. Hum Pathol 43: 229-237, 2012.

19. Tsujimoto Y: Role of $\mathrm{Bcl}-2$ family proteins in apoptosis: Apoptosomes or mitochondria? Genes Cells 3: 697-707, 1998

20. Swanton E, Savory P, Cosulich S, Clarke P and Woodman P: $\mathrm{Bcl}-2$ regulates a caspase-3/caspase-2 apoptotic cascade in cytosolic extracts. Oncogene 18: 1781-1787, 1999.

21. Park HJ, Jeon YK, You DH and Nam MJ: Daidzein causes cytochrome c-mediated apoptosis via the Bcl-2 family in human hepatic cancer cells. Food Chem Toxicol 60: 542-549, 2013.

22. Willis SN, Chen L, Dewson G, Wei A, Naik E, Fletcher JI, Adams JM and Huang DC: Proapoptotic Bak is sequestered by Mcl-1 and Bcl-xL, but not Bcl-2, until displaced by BH3-only proteins. Genes Dev 19: 1294-1305, 2005.

23. Xu SY, Xiao DJ, Luan YZ, Wang YS, Wang L and Shi K: Regulatory mechanism of cell cycle block and apoptosis in p53 mutated gastric cancer cells during cisplatin stress. J Shandong Univ (Health Sci) 46: 478-484, 2008 (In Chinese).

24. Moulin M, Carpentier S, Levade T and Arrigo AP: Potential roles of membrane fluidity and ceramide in hyperthermia and alcohol stimulation of TRAIL apoptosis. Apoptosis 12: 1703-1720, 2007.

25. Fuchs EJ, McKenna KA and Bedi A: p53-dependent DNA damage-induced apoptosis requires Fas/APO-1-independent activation of CPP32beta. Cancer Res 57: 2550-2554, 1997.

26. Klostergaard J, Leroux ME, Auzenne E, Khodadadian M, Spohn W, Wu JY and Donato NJ: Hyperthermia engages the intrinsic apoptotic pathway by enhancing upstream caspase activation to overcome apoptotic resistance in MCF-7 breast adenocarcinoma cells. J Cell Biochem 98: 356-369, 2006.

27. Woo SM, Choi YK, Kim AJ, Cho SG and Ko SG: p53 causes butein-mediated apoptosis of chronic myeloid leukemia cells. Mol Med Rep 13: 1091-1096, 2016.

28. Hollmann G, Linden R, Giangrande A and Allodi S: Increased p53 and decreased p21 accompany apoptosis induced by ultraviolet radiation in the nervous system of a crustacean. Aquat Toxicol 173: 1-8, 2016

29. Shih RH, Wang CY and Yang CM: NF-kappaB signaling pathways in neurological inflammation: A mini review. Front Mol Neurosci 8: 77, 2015.

30. Carter SL, Centenera MM, Tilley WD, Selth LA and Butler LM: $\mathrm{I} \kappa \mathrm{B} \alpha$ mediates prostate cancer cell death induced by combinatorial targeting of the androgen receptor. BMC Cancer 16: 141, 2016.

31. Seubwai W, Vaeteewoottacharn K, Kraiklang R, Umezawa K, Okada $\mathrm{S}$ and Wongkham S: Inhibition of $\mathrm{NF}-\kappa \mathrm{B}$ activity enhances sensitivity to anticancer drugs in cholangiocarcinoma cells. Oncol Res 23: 21-28, 2016. 